\title{
GEOPHYSICAL-GEOTECHNICAL INVESTIGATION OF AN OLD TAILINGS DAM FROM A MINE IN THE PERUVIAN HIGHLAND
}

\author{
Christ Jesus Barriga Paria¹, Jorge Pantaleon Barriga Gamarra², Eleonardo Lucas Pereira1
}

\begin{abstract}
A tailings dam is designed to operate under steady state flow conditions. An unconventional flow regime can be a threat to the integrity of its structure. In this sense, a correct geological-geotechnical investigation becomes a constant necessity, either by conventional mechanisms or even with the use of geophysical techniques. Geophysical methods play an important role in a geological description, in the mapping of flows and in monitoring changes over time. This paper presents the results of an investigation of the poledipole arrangements in Peru in lead, zinc, silver, and copper polymetallic ore mine with a height of 4,700 meters with the principal goal of to know the thickness of the anthropic sediment of the tailings deposit. The mine has an old tailings dam, where the electrical method was used by tomography to delineate possible areas of infiltration, to allow the mine closure plan required by the competent authorities, aiming, in the long term, the lowest risk to safety and health of the population, in addition to mitigating the associated environmental impacts.
\end{abstract}

Keywords: dam, tailings, electrical tomography, mining geophysics.

RESUMO. Uma barragem de rejeitos é projetada para operar sob condições de fluxo em estado estacionário. Um regime de fluxo não convencional pode ser uma ameaça à integridade de sua estrutura. Nesse sentido, uma correta investigação geológico-geotécnica tornase uma necessidade constante, seja por mecanismos convencionais ou mesmo com o uso de técnicas geofísicas. Os métodos geofísicos desempenham um papel importante em uma descrição geológica, no mapeamento de fluxos e no monitoramento de mudanças ao longo do tempo. Este artigo apresenta os resultados de uma investigação dos arranjos pólo-dipolo no Peru em uma mina de minério polimetálico de chumbo, zinco, prata e cobre, com uma altura de 4.700 metros, com o objetivo principal de conhecer a espessura do sedimento antrópico de uma antiga barragem de rejeitos. Esta barragem, onde o método elétrico foi utilizado pela tomografia elétrica para delinear possíveis áreas de infiltração, para permitir o plano de fechamento da mina exigido pelas autoridades competentes, visando, a longo prazo, o menor risco à segurança e saúde da população, além de mitigar os impactos ambientais associados.

Palavras-chave: barragem, rejeitos, tomografia elétrica, geofísica de mineração.

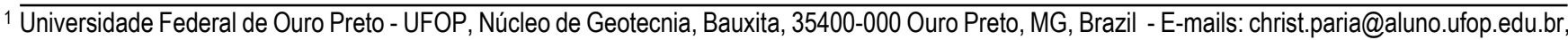
eleonardo@ufop.edu.br

2Jorge Basadre Grohmann National University, Department of Geology, Tacna, Peru - E-mail: jbarriga@unjbg.edu.pe
} 


\section{INTRODUCTION}

Geophysical research, with geotechnical purposes, has been considered necessary for monitoring and obtaining reliable results to be used in mining, especially with regard to the mine closure plan. For the present case study, the electrical method was used by tomography of the pole-dipole arrangement. Electrical tomography is generally used as a tool for studies of groundwater flow definition, contamination plume mapping (landfills/leaks) and groundwater well drilling. The electrical tomographies were performed in this study to obtain detailed information about the stratigraphy, identification of the presence or absence of groundwater, the presence of fractures or some type of infiltration.

The mining company, whose mine is the subject of the present study, had the need to verify the presence of groundwater, define stratigraphy in detail and its georesistivity, and finally determine the sediments from the old tailings dam, the goals of this work. It currently has a concentrator plant with a production capacity of 2,000 TPD (tons per day), with the possibility of expansion to $3000 \mathrm{TPD}$, with open pit mining ore treatment and underground exploration plan, in addition to the treatment of ore from other neighboring mines. It has a large polymetallic deposit, which includes zinc, silver and copper, which covers an area of approximately $2,100 \mathrm{ha}$.

Buselli and Lu (2001) considered tailings deposited in dams possess electrical properties that differ from surrounding materials, resistivity measurements can be used to evaluate leakage and propagation for environmental purposes in compliance with national standards. Geophysics has been used intensively for environmental solutions and the study of mine tailings investigations (Poisson et al., 2009). Campbell et al. (1999) in the last decades the use of geoelectric methods that work with resistivity for safety investigations of tailings dams has increased.
Since the technique is like the detection of leaks in other types of landfills or river embankments, such as those made by Van Tuyen et al. (2000), water table or even tailings variations of the internal structure Campbell \& Fitterman (2000). Thus, geophysical data show to be of high quality for geotechnical applications when covering areas such as construction or adequate monitoring, especially when a dam has mining material whose components have a considerable degree of danger to the environment (Grangeia et al., 2011).

\section{MATERIALS AND METHODS}

\section{Equipament}

The procedures adopted in the investigation used the technique of electrical tomography, with the following equipment:

- 10 French Channel Syscal Pro resistivity meters - IRIS instruments;

- Reels with $100 \mathrm{~m}$ of cable for VES;

- Cable configuration for PDS (Pole-Dipole Sounding) with a spacing of 10 meters;

- 800 DC power supply;

- 30 electrodes of stainless steel (dipoles) and 04 of steel $(A B)$.

\section{Data Collection Procedures}

After defining the research profiles, the cables were stretched and the electrodes positioned in the profile line (Fig. 1). The conductivity of these electrodes was verified to the equipment that will transmit the electric current, verifying the stability of the readings measured. The criteria for choosing the location of the research profiles of the field work program were based on the reference of the objectives of this work, such as 


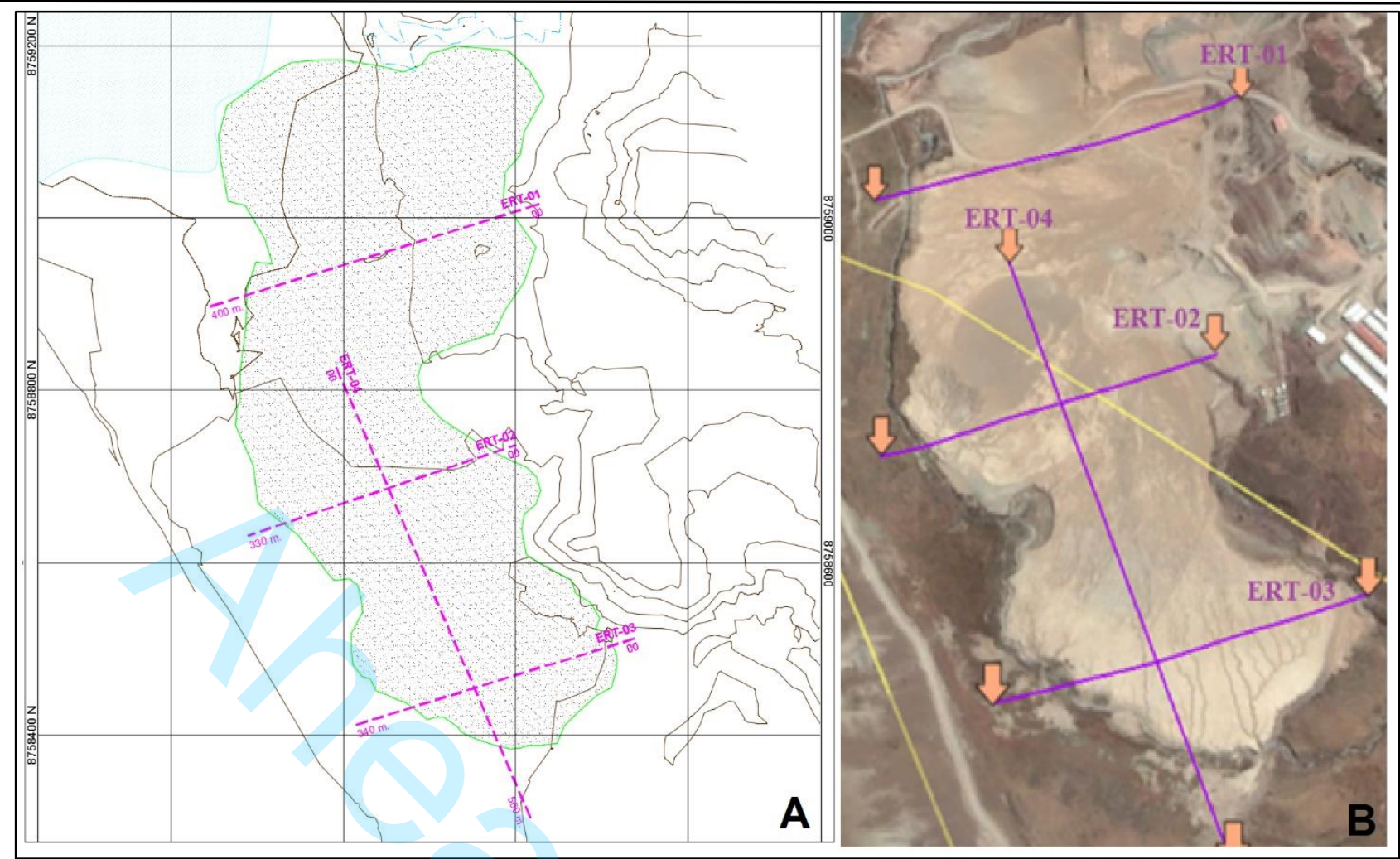

Figure 1- Location of tomographic profiles, (A: location by topography, B: satellite of Google Map)

defining the sediments from the old tailings, verifying the presence of groundwater, and defining the stratification georesistive.

Subsequently, an evaluation algorithm was executed, considering that, in adjacent points, the resistivity variation cannot exceed $25 \%$ for more or less. In the case of larger variations, it is necessary to repeat the points in question and a new data collection must be performed. Data from direct tests such as drilling are very important for this type of research, data such as Standard Penetration Test (SPT) values that were made by the mining company itself, which by stealth of information is not available for publication. However, the integration of the lithology observed was contrasted with the resistivities obtained from geophysical prospecting, checking the correct correspondence between the results and the resistivities.

\section{Geophysical Prospecting for Resistivity through the Electrical Tomography Technique}

Borges (2007), it is a friendly method and facilitates satisfactory results, which can use different types of array, and depending on the need these can be more detailed to obtain a better resolution. On the other hand, Bery \& Saad (2012), mentions that the resistivity method can be used for the identification of soil stratigraphy variations and is applicable to different studies of soil electrical resistivity. Haile (2014), geophysical techniques are routinely used as part of geological investigations to provide information such as dimensions and depths of the subsoil and therefore perform a geological mapping.

Soil and rocks are good conductors of electric current, depending on the content of metallic minerals, moisture content and mineralization of the water that occupies the interstitial spaces and sedimentary formations. There are no fixed limits for values of electrical resistivity of sediments and 
sedimentary rocks, meanwhile, mean values can be established through statistics (Todd, 1980).

Keller \& Frischknecht (1966), temperature also influences the electrical conductivity of rocks, the resistivity of geological materials decreases with increasing temperature, due to the greater mobility of ions in water. The resistivity of geological materials increases as the temperature drops, reaches a maximum of $0^{\circ} \mathrm{C}$, since the freezing water reduces the movement of electrolytes. Gadallah \& Fisher (2009) these are the most important characteristics that define the resistivity of the physical environment. In geological formations such as those observed in the area investigated in this investigation, resistivity values vary from units of $\Omega m$ for soils and rocks with different levels of mineralization and moisture.

Orellana (1972), the difficulty that a body presents in letting itself be traversed by an electric current is given the name of electrical resistivity or electrosensitivity, as is more commonly referred to in the literature. This property is based on the Ohm's law, by which, having knowledge of the injected current $(\mathrm{I})$, of the potential difference $(\Delta \mathrm{V})$ and of the positions of the injection points and current collection (current electrodes and potential respectively).

Dahlin \& Zhou (2004), carried out after having conducted tests and analyzing the advantages and limitations of the electrode arrays according to the effects of the anomalies, the authors recommend a distribution of pole-dipole (PDS) type electrodes, being the geology of the area under study that categorically determines the array. This probing, also called tripole, consists of three mobile electrodes along the motion profile, one of the current $(A)$ and two of potential $(M N)$ whose spacing $(a=M N)$ remains constant.

\section{Pole-dipole survey}

Keller and Frischknecht (1966), the pole-dipole arrangement has been widely used in surveys of electric roads oriented to the exploration of groundwater and mining. This happens depending on some of its positive features, such as the ease of operation in the field and its symmetry that is peculiar to it. The array and distribution of the electrodes used according to the pole-dipole method in the field work are shown in Figure 2.

The measurements performed provided the lateral and vertical resistivity changes of the subsoil. These changes made possible the construction and presentation of a $2 \mathrm{D}$

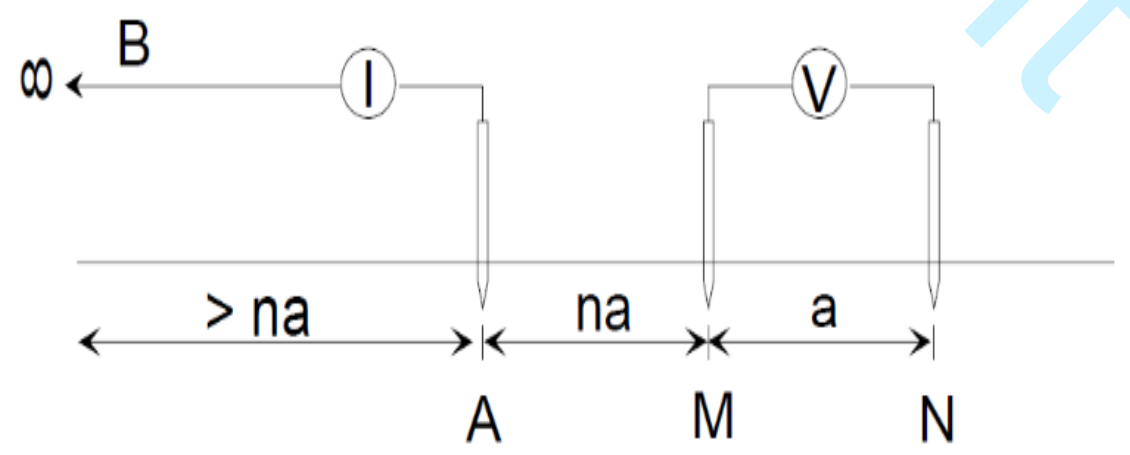

Figure 2- Pole-dipole array 


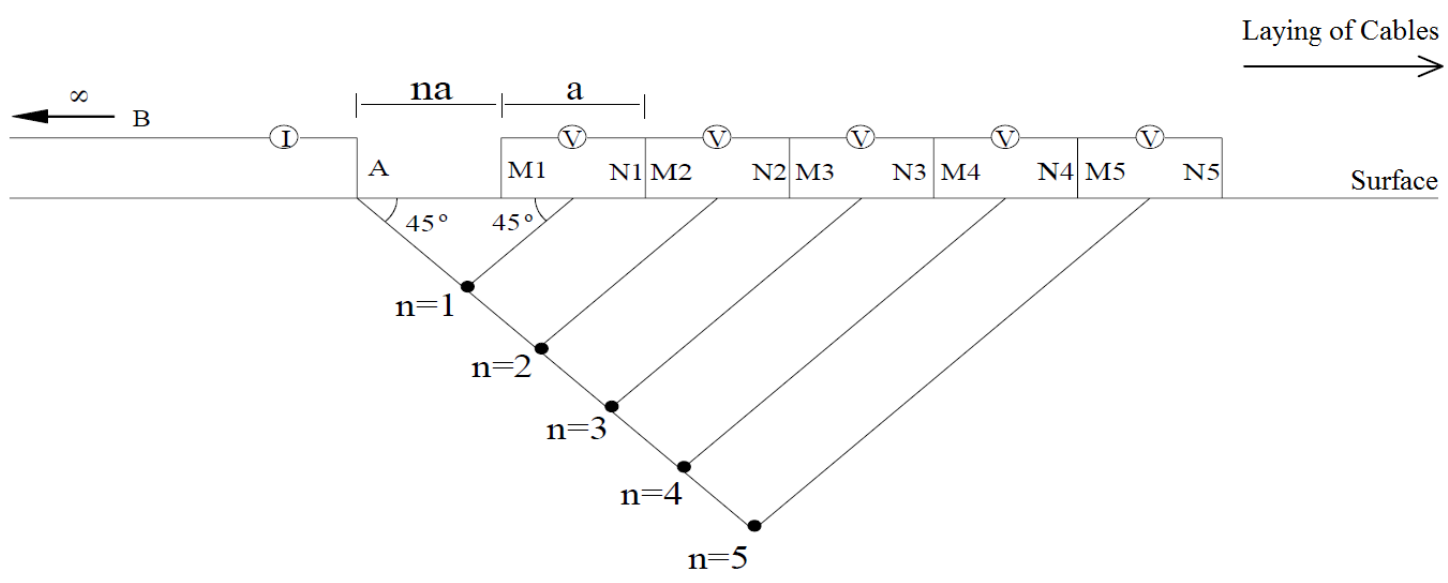

Figure 3- Representation of pseudosections through the pole-dipole technique

model, in order to graphically represent the so-called "pseudosection", as shown in Figure 3.

To perform the readings, the current electrodes were initially positioned at points 1-2 of the graph (Fig. 3), while the potential electrodes occupied positions $3-4$, so that the separation factor of the device dipoles was $n=1$ (I) and potential $(\Delta \mathrm{V})$, which fed Equation 1.

$$
\rho_{a}=\pi * n(n+1)(n+2) * a \frac{\Delta V}{I}
$$

Where:

$\rho_{a}$ : electrical resistivity;

a: spacing between electrodes
With the values replaced, the resistivity value corresponding to the pair of electrodes in positions 1-2 and 3-4 was obtained. The method suggests the construction of lines inclined at $45^{\circ}$, so that, at the point where they are cut, the measured apparent resistivity value is assigned. The continuity of the procedure was therefore followed by the measure corresponding to the pair of positions $1-2$ and 4-5 and so on.

It should be noted that this pseudosection tracing procedure is only a graphical convention and does not imply that the depth of investigation of the device is given by the intersection of the two $45^{\circ}$ lines. The pseudosection provides

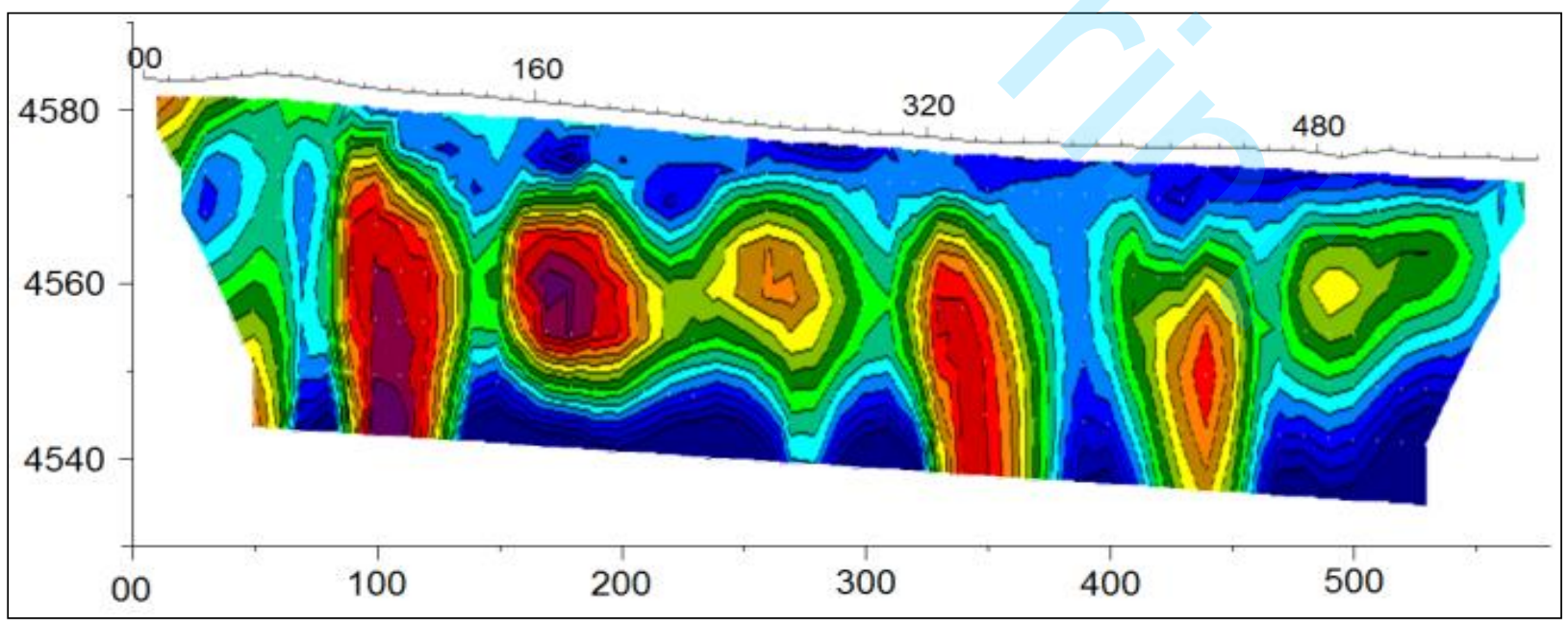

Figure 4- Investment model by topography 
Table 1. Range of Resistivities Generated by ERT and corresponding Litology

\begin{tabular}{|c|c|c|}
\hline \multicolumn{3}{|c|}{ Resistixity ( $\Omega-m)$} \\
\hline 35 & 187 & 1000 \\
\hline \multicolumn{3}{|c|}{ Probable geological lithology } \\
\hline $\begin{array}{l}\text { Fine sand and wet to } \\
\text { saturated silty of the } \\
\text { tailings dam. } \\
\text { Lacustrine clay with } \\
\text { sands and / or fragments } \\
\text { of rocks. }\end{array}$ & $\begin{array}{l}\text { Glaciofluvial deposit and } \\
\text { / or morass deposit with } \\
\text { clays and lightly } \\
\text { compacted stones. }\end{array}$ & $\begin{array}{l}\text { Glaciofluvial deposit } \\
\text { and/or moraines } \\
\text { with clays and } \\
\text { compacted stones. }\end{array}$ \\
\hline
\end{tabular}

an image very close to the distribution of resistivity in the subsoil. However, the image provided is distorted.

\section{PROCESSING OF DATA}

Initially, we set out to organize the information obtained by all pairs and to calculate the apparent resistivity value, making a layered arrangement. For a separation of the electrodes, "A" was designated the first layer, for "NA" the second layer and so, successively, until layer "N". This information was converted into a one-dimensional file, to be processed and obtained a two-dimensional image, which allowed analyzing, in a simple way, the geological information, the information of the subsoil material and the electric and stratigraphic characteristics.

The software used to visualize the data was with the Prosys $\mathrm{II}$, and for the interpretation of inversion data, the RES2DINV (Loke et Barker 1995), using the finite element method and the least squares solution. The topography was then inverted (Fig. 4).

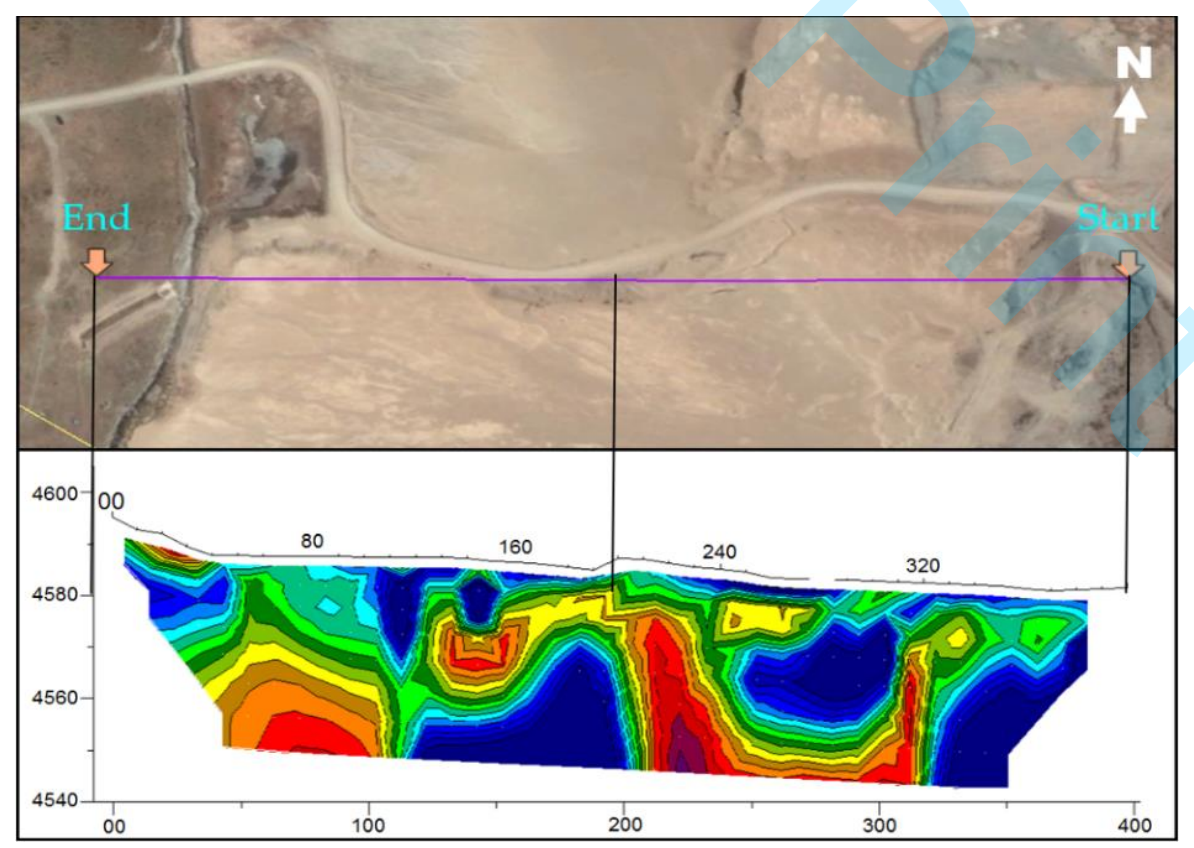

Figure 5- Satellite image of the ERT-01 location and its profile 


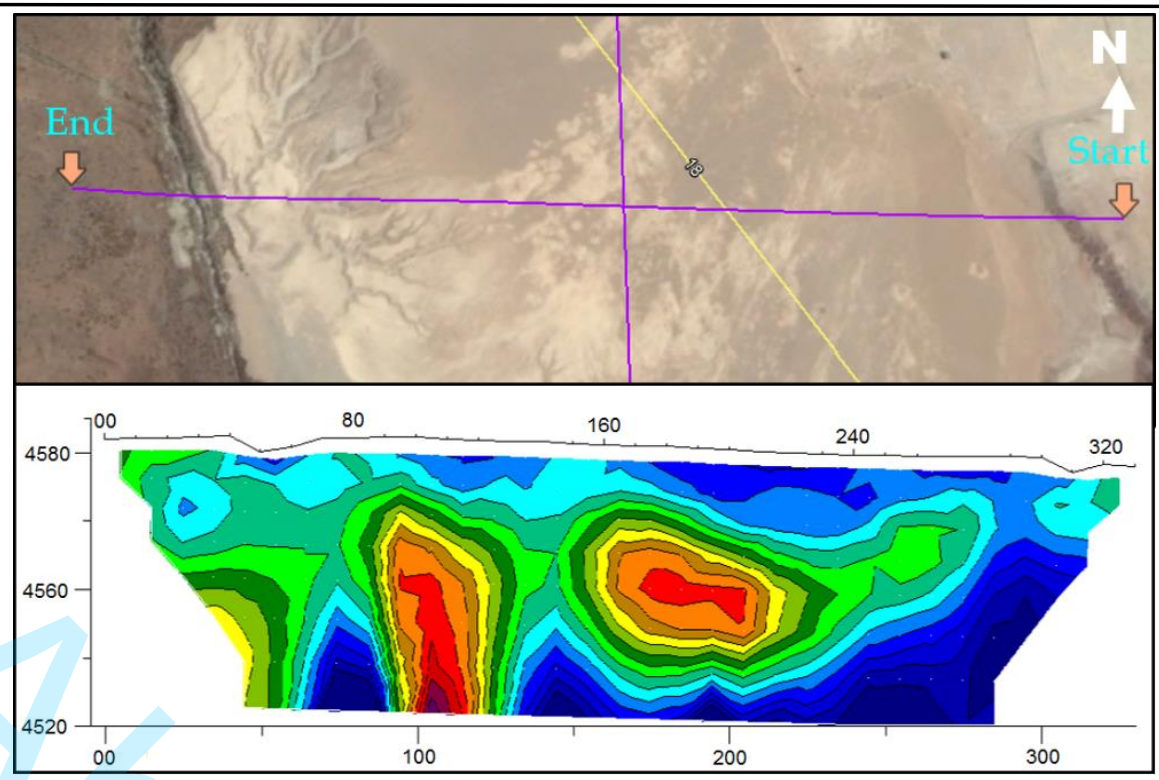

Figure 6 - Satellite image of the ERT-02 location and respective its profile

\section{RESULTS AND ANALYSIS}

\section{Range of resistivities}

During resistivity processing, the software assigned a color to each resistivity contrast, progressively varying the color tone, as shown in Figure 4, which shows the topographic inversion model. The range of color variation is shown in Table 1, where they were separated into three groups according to the geological formations in the area under investigation. Palacky (1987) made an update of the distribution of the resistivities and the type of geological material that would correspond to it, representing it by the colorations and its variations of tonalities according to the applied geophysics. Telford et al. (1990) then Reynolds (1997), they also present a high range of resistivity values for different geologies for applications in mineral exploration, hydrocarbons and groundwater, with emphasis on the use of geophysics for engineering and environmental research.

\section{Description of electric resistivity tomographic}

The results of the electrical scans were contrasted with the lithology found in the PTS Wash Boring perforations, observing a good correlation between the resistivities and the geological formations. The results are important for geological interpretation, and they were based on professional experience, adding field observations of geological formations, resistivities obtained from geophysical prospecting, and a contrast with references of resistivities calculated by several authors, which assign a resistivity value to different geological formations.

It was observed that the present study provided the possibility of including technical knowledge regarding risk management to the technical staff of the mining company. The presented gain corroborates with the understanding of the behavior of the soil that constitutes a dam of tailings of relevance. The lines of electric resistivity tomographic scans used to investigate the tailings dam allowed to define 3 types of georesistivity strata that are detailed below, depending on the resistivity. Descriptions of ERT's are presented in Table 2. 


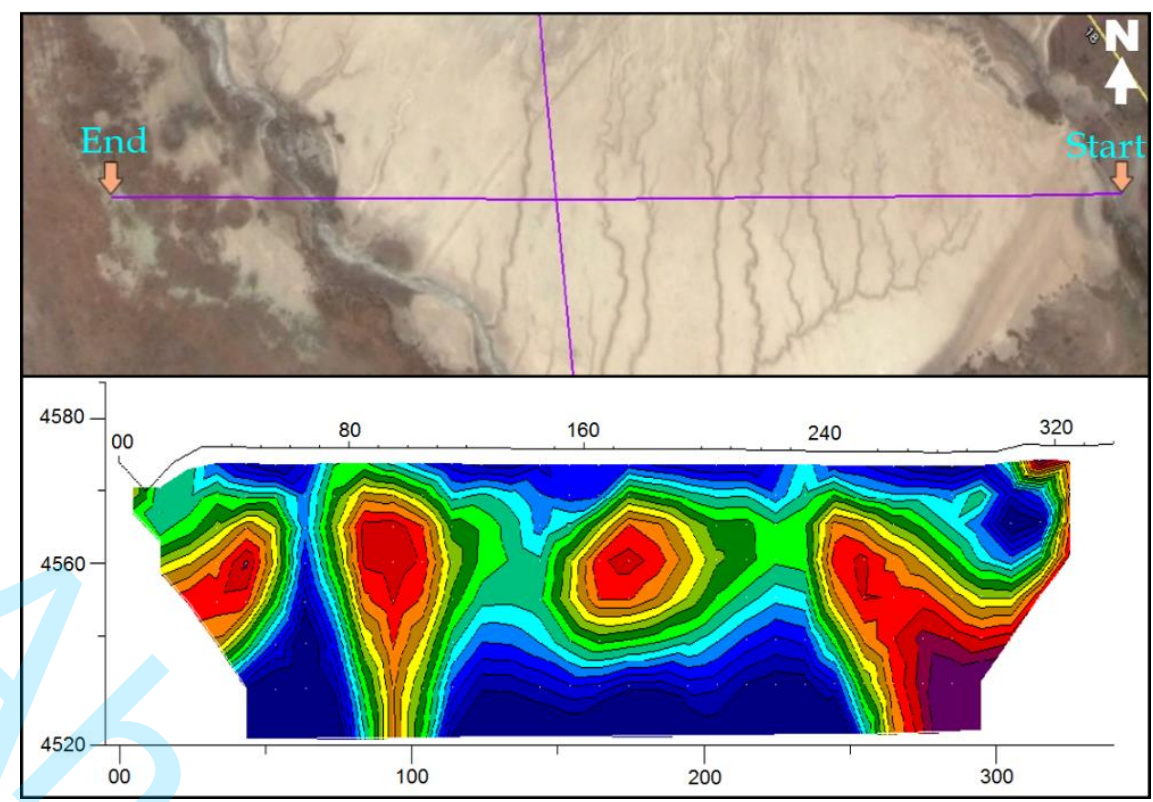

Figure 8. Satellite image of the ERT-03 location and respective its profile

- Resistivities less than $80 \Omega$-m are represented by colors ranging from light blue to dark blue. In the tomographies, they are presented in the superficial part that would correspond to the fine sands with silts, wet to saturated, coming from the tailings dam, with a thickness ranging from zero to $10 \mathrm{~m}$, on average. When these colors are below the stratum defined by the green to red colors, they would correspond to sedimentary formations, such as very wet to saturated shales, located between 15 and $20 \mathrm{~m}$ depth, as seen in the 4 ERT's.

- Resistivities between 80 and $300 \Omega-m$ are represented by colors ranging from green to yellow. Geologically, these resistivities would correspond to a transition between the silty sands for the brown formations (deposits produced by the

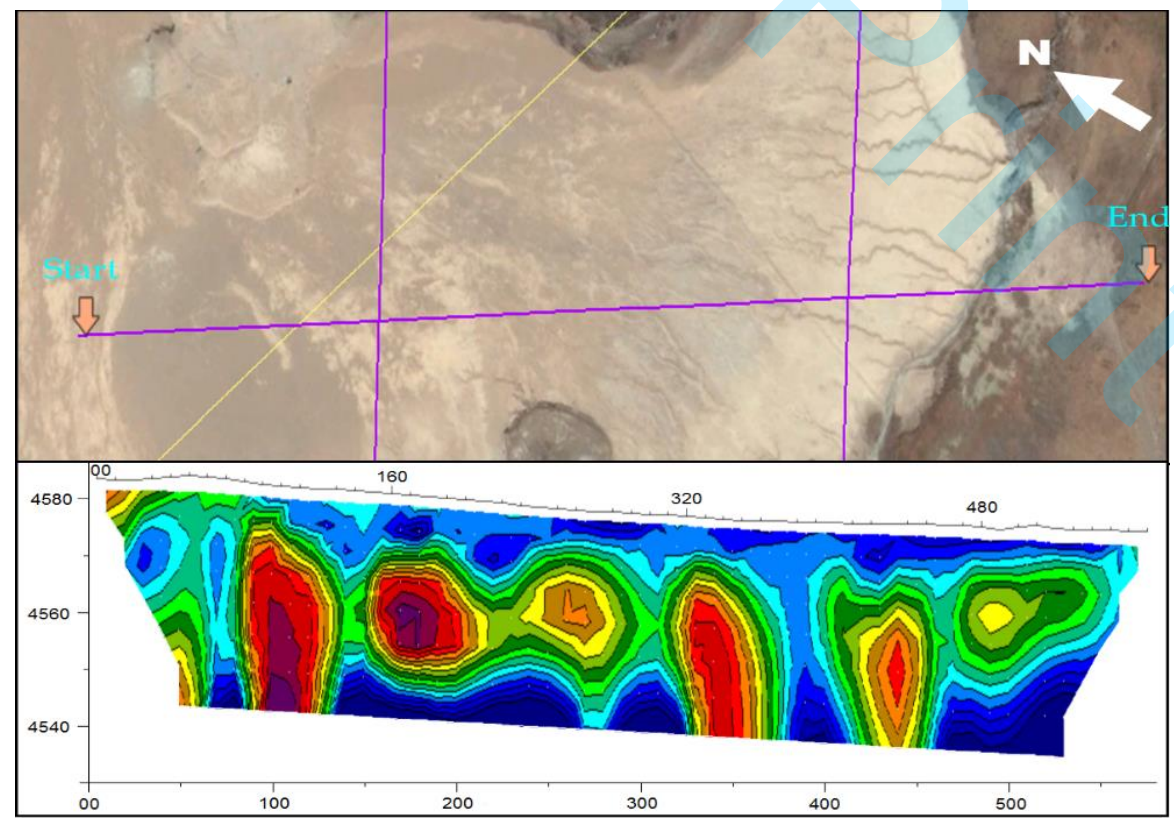

Figure 7- Satellite image of the ERT-04 location and respective its profile 
glaciers when moving) and/or glacial-fluvial with fine to coarse sands. As the resistive values increase, it is an indicator that the sediment granulometry is coarser and/or more compact. It has an average thickness of 3 to $8 \mathrm{~m}$.

- Resistivities between 300 and $1000 \Omega$-m are represented by brown to purple colors. Geologically, these representations correspond to very compact formations or sound rocks. In the study, they would be associated with the more compact glacial and/or even glacial-fluvial deposits, as presented in the 4 tomographies made in the tailings dam area.

The ERT-01 profile is located at the head of the tailings dam, as shown in Figure 5 . The profile has a length of $400 \mathrm{~m}$ from northeast to southwest.

The ERT-02 profile was performed in parallel with the ERT01 , located $260 \mathrm{~m}$ downstream. It has a length of $330 \mathrm{~m}$, as shown in Figure 6.

The ERT-03 profile (Fig. 7) was defined in parallel to the previous ERT. It is located downstream, distant at $250 \mathrm{~m}$ from the ERT-02 profile. Its route has a total length of $340 \mathrm{~m}$, from northeast to southwest.

The tomographic profile ERT-04 is configured transversely to the previous lines. It passes approximately through the middle of the dam, with a length of $500 \mathrm{~m}$. The profile is shown in Figure 8.

\section{CONCLUSIONS}

The studies carried out in this research have shown that, in addition to the conventional instrumentation, oriented to the measurement of poropressions, horizontal displacements, repressions, etc., that geophysical studies can also contribute to the control mechanisms of a tailings dam. A periodic geophysical investigation, performed before, during and after the decommissioning of the structure, is fundamental to the knowledge of the behavior throughout its life period, also contributing to the risk management associated with the dam. The relatively recent threedimensional geophysical results (Fig. 9) become convenient for a dam. This type of study contributes to reinforcing the observations coming from the two-dimensional model, as well as providing knowledge of some features in the subsoil.

Finally, it is pointed out that for the proper evaluation of a structure, with respect to the geotechnical behavior of tailings and a dam, studies of this nature are relevant. The application of geophysics as a tool for the internal structural visualization of the structure allows interpreting its updated behavior since many structures are dimensioned from values obtained in

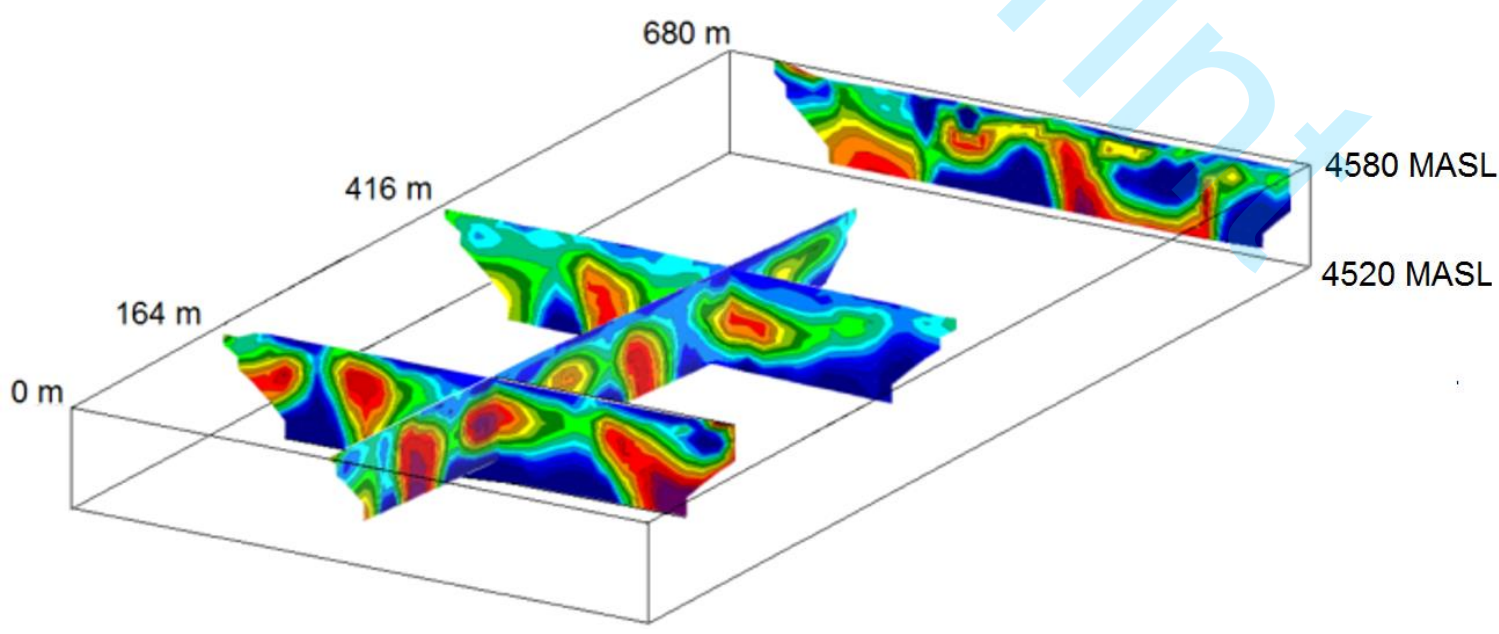

Figure 9-Three-dimensional positioning of the four profiles 
laboratory tests. Often, the results of these differed when compared to the field condition.

Electrical tomography showed a particularly interesting and consistent tool for the evaluation of the tailings of the polymetallic ore, making it possible to know the thickness, the general granulometric classification, the stratigraphy and even the humidity, in an approximate way.

In general, when this is done, the project results in the sense of safety, since the structures are controlled periodically, avoiding risks of ruptures or even simpler anomalies, and reducing, therefore, possibilities of associated environmental impacts.

\section{ACKNOWLEDGMENT}

The authors would like to thank the Geotechnical Nucleus of the Universidade Federal de Ouro Preto for their help in working with the precious discussions and theoretical contributions. This study was financed in part by the Coordenação de Aperfeiçoamento de Pessoal de Nível Superior - Brasil (CAPES) - Finance Code 001, which allowed us to improve the research. 
Table 2. Results (description) of the ERTs performed in the dam

\begin{tabular}{|c|c|c|c|c|c|}
\hline Layer & $\begin{array}{c}\text { Resistivity } \\
\Omega-m\end{array}$ & ERT-01 & ERT-02 & ERT-03 & ERT-04 \\
\hline $\begin{array}{c}\text { Blue } \\
\text { to } \\
\text { Sky Blue }\end{array}$ & 20 a 80 & $\begin{array}{l}\text { Saturated silty fine sand. } \\
\text { Corresponding to the tailings dam, } \\
\text { it is between } 00 \text { and } 13 \mathrm{~m} \text { deep. } \\
\text { They are also present between } 15 \\
\text { and } 20 \mathrm{~m} \text { deep, which would } \\
\text { correspond to clays of lacustrine } \\
\text { origin with sands and/or fragments } \\
\text { of rocks. }\end{array}$ & $\begin{array}{l}\text { Saturated silty fine sand. } \\
\text { Corresponding to the tailings dam, } \\
\text { it is between } 00 \text { and } 7 \mathrm{~m} \text { deep. } \\
\text { They are also present between } 15 \\
\text { and } 20 \mathrm{~m} \text { deep, which would } \\
\text { correspond to clays of lacustrine } \\
\text { origin with sands and/or fragments } \\
\text { of rocks. }\end{array}$ & $\begin{array}{l}\text { Saturated silty fine sand. } \\
\text { Corresponding to the tailings dam, } \\
\text { it is between } 00 \text { and } 14 \mathrm{~m} \text { deep. } \\
\text { They are also present between } 14 \\
\text { and } 18 \mathrm{~m} \text { deep, which would } \\
\text { correspond to clays of lacustrine } \\
\text { origin with sands and/or fragments } \\
\text { of rocks. }\end{array}$ & $\begin{array}{l}\text { Saturated silty fine sand. } \\
\text { Corresponding to the tailings dam, } \\
\text { it is between } 00 \text { and } 10 \mathrm{~m} \text { deep. } \\
\text { They are also present between } 15 \\
\text { and } 20 \mathrm{~m} \text { deep, which would } \\
\text { correspond to clays of lacustrine } \\
\text { origin with sands and/or fragments } \\
\text { of rocks. }\end{array}$ \\
\hline
\end{tabular}

Fluvial reservoir glacier and/or Fluvial reservoir glacier and/or Fluvial reservoir glacier and/or Fluvial reservoir glacier and/or moraines with slightly compacted moraines with slightly compacted moraines with slightly compacted moraines with slightly compacted

\begin{tabular}{|c|c|c|c|c|c|}
\hline $\begin{array}{l}\text { Green } \\
\text { to } \\
\text { yellow }\end{array}$ & 80 a 300 & $\begin{array}{l}\text { clays and pebbles. Located } \\
\text { between the progressions from } 00 \\
\text { to } 50 \mathrm{~m} \text { and } 295 \text { to } 315 \mathrm{~m} \text {, the } \\
\text { flower of the earth and/or very } \\
\text { close to the surface. They are } \\
\text { practically outside the tailings dam } \\
\text { (Figure 5). }\end{array}$ & $\begin{array}{l}\text { clays and pebbles. Located } \\
\text { between the progressions from } 00 \\
\text { to } 50 \mathrm{~m} \text { and } 310 \mathrm{~m} \text { at the end of the } \\
\text { ERT, the flower of the earth and/or } \\
\text { very close to the surface. They are } \\
\text { practically outside the tailings dam } \\
\text { (Figure 6). }\end{array}$ & $\begin{array}{l}\text { clays and pebbles. Located } \\
\text { between the progressions from } 00 \\
\text { to } 30 \mathrm{~m} \text { and } 310 \mathrm{~m} \text { at the end of the } \\
\text { ERT, the flower of the earth and/or } \\
\text { very close to the surface. They are } \\
\text { practically outside the tailings dam } \\
\text { (Figure } 7 \text { ). }\end{array}$ & $\begin{array}{l}\text { clays and pebbles. Located } \\
\text { between the progressions from } 00 \\
\text { to } 30 \mathrm{~m} \text { and } 310 \mathrm{~m} \text { at the end of the } \\
\text { ERT, the flower of the earth and/or } \\
\text { very close to the surface. They are } \\
\text { practically outside the tailings dam } \\
\text { (Figure 8). }\end{array}$ \\
\hline $\begin{array}{l}\text { Brown } \\
\text { to } \\
\text { Purple }\end{array}$ & 300 a 1000 & $\begin{array}{l}\text { Glaciofluvial deposit and/or } \\
\text { moraines with compacted clay and } \\
\text { gravel. }\end{array}$ & $\begin{array}{l}\text { Glaciofluvial deposit and/or } \\
\text { moraines with compacted clay and } \\
\text { gravel. }\end{array}$ & $\begin{array}{l}\text { Glaciofluvial deposit and/or } \\
\text { moraines with compacted clay and } \\
\text { gravel. }\end{array}$ & $\begin{array}{l}\text { Glaciofluvial deposit and/or } \\
\text { moraines with compacted clay and } \\
\text { gravel. }\end{array}$ \\
\hline
\end{tabular}




\section{REFERENCES}

BERY AA \& SAAD R. 2012. Tropical clay sand soil's behavior analysis and its empirical correlations via geophysics electrical resistivity method and engineering soil characterizations. International Journal of Geosciences, 3: 111-116.

BORGES WR. 2007. Caracterização geofísica de alvos rasos com aplicações no planejamento urbano e meio ambiente: estudo sobre o sítio controlado do IAG/USP. Doctorate Thesis, Instituto de Astronomia, Geofísica e Ciências Atmosféricas, IAG/USP, São Paulo, Brazil. 256 pp.

BUSELLI G \& LU K. 2001. Groundwater contamination monitoring with multichannel electrical and electromagnetic methods. J. Appl. Geophys., 48:11-23 pp.

CAMPBELL DL \& FITTERMAN DV. 2000. Geoelectrical Methods for Investigating Mine Dumps. In: 5th International Conference on Acid Rock Drainage (ICARD 2000). Proceedings. Denver, 21-24 May 2000, 1513-1523 pp.

CAMPBELL DL, HORTON RJ, BISDORF RJ, FEY DL, POWERS MH \& FITTERMAN DV. 1999. Some geophysical methods tailings/mine waste work. In: 6th International Conference on Tailings and Mine Waste'99. Proceedings. Fort Collins, Colorado, 24-27 pp.

CAMPBELL DL, HORTON RJ \& BEANLAND S. 2000. Geoelectrical Laboratory Measurements of Materials from May Day Mine Dump, Southwestern Colorado: U.S. Geological Survey Open-File Report 00-382. 27 pp.

DAHLIN T \& ZHOU B. 2004. A numerical comparison of 2D resistivity imaging with 10 electrode arrays. Geophysical Prospecting, 52: 379-398.

GADALLAH MR \& FISHER R. 2009. Exploration Geophysics: An Introduction. Springer-Verlag Berlin, Heidelberg, 257 pp.

GRANGEIA C, ÁVILA P, MATIAS M, FERREIRA DA SILVA E. 2011. Mine tailings integrated investigations: the case of Rio tailings (Panasqueira Mine, Central Portugal). Eng. Geol., 123: 359-372.

HAILE T \& ATSBAHA S. 2014, Electrical Resistivity tomography, VES and magnetic surveys from dam site characterization, Wukro, Northern Ethiopia. Journal of African Earth Sciences, 97: 67-77.
KELLER GV \& FRISCHKNECHT FC. 1966. Electrical methods in geophysical prospecting. Oxford: Pergamon Press. 517 pp.

LOKE MH \& BARKER RD. 1995. Least-square inversion of apparent resistivity pseudosections. Geophysics, 60: 16821690.

ORELLANA E. 1972. Prospección geoeléctrica en corriente continua. Ed. Paraninfo, Madrid, 523 pp.

PALACKY GV. 1987. Resistivity characteristics of geologic targets. In: Electromagnetic Methods in Applied Geophysics, Vol 1, Theory, $1351 \mathrm{pp}$.

POISSON J, CHOUTEAU M, AUBERTIN M \& CAMPOS D. 2009. Geophysical experiments to image the shallow internal structure and the moisture distribution of a mine waste rock pile. Journal of Applied Geophysics, 67: 179192.REYNOLDS JM. 1997. An Introduction to Applied and Environmental Geophysics. Chichester: John Wiley and Sons Ltd. 796 pp.

TELFORD WM, GELDART LP, SHERIFF RE. 1990. Applied Geophysics. Cambridge University Press, 770 pp.

TODD DK. 1980. Groundwater Hydrology. New York: John Wiley and Sons, 2nd ed., 535 pp.

VAN TUYEN D, CANH T \& WELLER A. 2000. Geophysical investigations of river dikes in Vietnam. Eur. J. Environ. Eng. Geophys., 4: 195-206. 